\title{
Kualitas Air dan Pertumbuhan Pembesaran Ikan Patin dengan Teknologi Biopori di Lahan Gambut
}

\author{
[Water quality and growth of Catfish culture with biopori technology \\ in peatlands]
}

\section{Amrih Manunggal' ${ }^{1}$ Rahmat Hidayat ${ }^{2}$, Siti Mahmudah $^{1}$, Dinno Sudinno ${ }^{3}$, Adang Kasmawijaya ${ }^{3}$}

1)Dinas Ketahanan Pangan, Pertanian dan Perikanan Kota Banjarbaru, ${ }^{2}$ Balai Perikanan Budidaya Air Tawar Mandiangin, ${ }^{3)}$ Sekolah Tinggi Perikanan Jurusan Penyuluhan Perikanan Bogor

Diterima: 20 Januari 2018; Disetujui: 12 Maret 2018

\begin{abstract}
Abstrak
Air yang dapat digunakan sebagai media budidaya harus mempunyai standar kuantitas dan kualitas yang sesuai dengan persyaratan hidup ikan, beberapa parameter kualitas air yang cukup penting bagi ikan budidaya yaitu suhu, $\mathrm{pH}$ dan oksigen terlarut. Berdasarkan hasil pengukuran selama 90 hari pembesaran ikan patin di lahan gambut di peroleh data $\mathrm{pH}$ air di kolam dengan sistem biopori berkisar antara 5,8 - 6,3 sedangkan di kolam tanpa biopori pH air selama pembesaran berkisar antara 5,1-6,7. Tingkat pH air di kolam dengan biopori lebih stabil di bandingkan kolam tanpa biopori walaupun tidak berbeda nyata. Saat awal penebaran $\mathrm{pH}$ air di kolam tanpa biopori lebih tinggi dari pada kolam biopori namun menurun saat mulai pemeliharaan ikan. Selama 90 hari pembesaran ikan patin di kolam biopori menghasilkan data pertambahan bobot 437,8 gram sedangkan di kolam tanpa biopori pertambahan bobot 420,3 gram.
\end{abstract}

Kata kunci: kualitas air; lahan gambut; teknologi biopori

\section{Abstract}

Water that can be used as a culture medium should have a standard quantity and quality in accordance with the requirements of life of the fish, some parameters of water quality are important enough for the fish cultivation of temperature, $\mathrm{pH}$ and dissolved oxygen. Based on the measurement results for 90 days of catfish enlargement on peatlands obtained data on the $\mathrm{pH}$ of water in ponds with biopori system ranged between 5.8 to 6.3 whereas in ponds without biopori water $\mathrm{pH}$ during magnification ranged from 5.1 to 6.7 . The $\mathrm{pH}$ level of water in ponds with biopori is more stable than ponds without biopori although not significantly different. When the initial distribution of water $\mathrm{pH}$ in the pond without biopori higher than the pond biopori but decreased when the fish began to start. During 90 days of catfish enlargement in biopori ponds resulted in weight gain data of 437.8 grams while in ponds without biopori weighing 420.3 grams.

Keywords: biopore technology; peatland; water quality

Penulis korespondensi

Amrih Manunggal | amrih.manunggal@yahoo.com 


\section{PENDAHULUAN}

Dalam suatu kegiatan budidaya perikanan kualitas air sangat penting untuk diperhatikan, sebab air adalah media utama bagi ikan untuk hidup

Air yang dapat digunakan sebagai media budidaya harus mempunyai standar kuantitas dan kualitas yang sesuai dengan persyaratan hidup ikan. Beberapa parameter kualitas air yang cukup penting bagi ikan budidya yaitu suhu, $\mathrm{pH}$ dan oksigen terlarut. Suhu air yang optimum untuk selera makan ikan antara $22-29^{\circ} \mathrm{C}$, pada suhu tersebut ikan akan makan dengan rakus, hal ini terjadi pada waktu pagi hari dan sore hari. Oleh karena itu pemberian makan yang paling baik adalah pagi hari dan sore hari (Handayani \& Nofyan 2015).

Di lahan gambut $\mathrm{pH}$ air kolam sangat berpengaruh pada pertumbuhan ikan. Pada $\mathrm{pH}$ rendah kandungan oksigen terlarut akan berkurang, sebagai akibatnya konsumsi oksigen akan menurun, aktivitas pernafasan naik dan selera makan akan berkurang. Disebutkan Adriyanto dkk. 2012), pH yang ideal dimana ikan patin akan mengalami pertumbuhan yang optimum berkisar antara 6,5-9,0. Sedangkan Syahrizal \& Arifin (2017) menjelaskan bahwa ikan air tawar mempunyai titik kritis asam pada $\mathrm{pH} 4,0$ dan titik kritis basa pada $\mathrm{pH} 11,0$. Kadar oksigen terlarut yang baik bagi pertumbuhan ikan patin antara
7,0-8,4 ppm, namun pada kandungan oksigen terlarut sebesar 5 ppm masih cukup baik bagi kehidupan ikan.

Menurut Andayani (2005), $\mathrm{pH}$ adalah cerminan derajat keasaman yang diukur dari jumlah ion hidrogen menggunakan rumus $\mathrm{pH}=-\log (\mathrm{H}+)$. Air murni terdiri dari ion $\mathrm{H}+$ dan $\mathrm{OH}$-dalam jumlah berimbang hingga $\mathrm{pH}$ air murni biasa 7 . Makin banyak banyak ion $\mathrm{OH}+$ dalam cairan makin rendah ion $\mathrm{H}+$ dan makin tinggi $\mathrm{pH}$. Cairan demikian dise-but cairan alkalis. Sebaliknya, makin banyak $\mathrm{H}+$ makin rendah $\mathrm{pH}$ dan cairan tersebut bersifat masam. Nilai $\mathrm{pH}$ antara $7-9$ sangat memadai kehidupan bagi air kolam. Namun, pada keadaan ter-tentu, dimana air dasar kolam memiliki potensi keasaman, $\mathrm{pH}$ air dapat turun hingga mencapai 4. Menurut Djoko-setiyanto dkk (2005), laju peningkatan pH akan dilakukan oleh nilai pH awal. Sebagai contoh: kebutuhan jumlah ion karbonat perlu ditambahkan utuk meningkatkan satu satuan $\mathrm{pH}$ akan jauh lebih banyak apabila awalnya 6,3 dibandingkan hal yang sama dilakukan pada $\mathrm{pH}$ 7,5. kenaikan $\mathrm{pH}$ yang akan terjadi diimbangi oleh kadar $\mathrm{CO}_{2}$ terlarut dalan air. Sehingga, $\mathrm{CO}_{2}$ akan menurunkan $\mathrm{pH}$. Selanjutnya dikatakan bahwa pertumbuhan itu disebabkan pertambahan jaringan akibat dari pembelahan sel secara mitosis. Hal ini terjadi apabila ada 
kelebihan input energi dan asam amino (protein) berasal dari makanan.

Menurut Amin dkk (2010), makanan yang dimanfaatkan oleh ikan patin, bila terlalu banyak nabati akan berpotensi menimbulkan masalah baru dan mengganggu pertumbuhan. Kecepatan pertumbuhan tergantung pada jumlah makanan yang diberikan, ruang, suhu, dalamnya air dan faktor-faktor lainnya. Sedangkan Ariyanto \& Utami (2006) menyatakan bahwa pertumbuhan sangat dipengaruhi oleh sejumlah faktor seperti perbedaan genetik dan kekerabatan, kemampuan memanfaatkan makanan dan kepadatan populasi.

Pertumbuhan merupakan parameter dalam budidaya ikan terutama untuk ikan yang bernilai ekonomis, karena pertumbuhan akan menentukan nilai produksi. Pertumbuhan dapat dirumuskan sebagai pertambahan dari ukuran panjang atau berat dalam suatu waktu. Menurut Ananda dkk. (2015) pakan buatan yang digunakan oleh pembudidaya patin mengandung protein yang tidak dapat diserap secar optimal oleh ikan patin. Oleh karena itu pemberian tambahan ezim protease akan dapat mengatasi hal ini.

Pengujian kualitas air khususnya $\mathrm{pH}$ untuk mengetahui efektifitas penggunaan lubang-lubang biopori pada stabilitas $\mathrm{pH}$ air kolam lahan gambut pada saat hujan. Pengukuran pertum- buhan ikan patin adalah untuk mengetahui dan membandingkan pertumbuhan ikan patin di kolam dengan perlakuan sistem biopori dan tanpa biopori. Secara umum, tujuan dan sasaran yang hendak diwujudkan pada kegiatan ini meliputi: (a) untuk mengetahui penga-ruh sistem biopori pada kualitas air khususnya $\mathrm{pH}$ air kolam pembesaran ikan patin di lahan gambut; dan (b) untuk mengetahui dan membandingkan pertumbuhan ikan patin pada kolam biopori dan tanpa biopori di lahan gambut.

\section{BAHAN DAN METODE}

Metode yang digunakan dalam penerapan pemberian kapur sistem biopori untuk mempertahankan $\mathrm{pH}$ air kolam budidaya ikan patin (Pangasius sp.) di lahan gambut adalah:

\section{Pengukuran kualitas air}

Langkah pertama adalah menetapkan konfigurasi pengujian kualitas air kolam. Kegiatan pengujian kualitas air kolam dilakukan setiap bulan selama pembesaran ikan patin yang akan dilaksanakan selama empat bulan selama tahun 2016. Kegiatan pengujian akan dilaksanakan di instalasi budidaya ikan lahan gambut Kabupaten Pulang Pisau Propinsi Kalimantan Tengah.

Bahan dan alat yang digunakan adalah: (a) kertas lakmus/pH meter; (b) DO meter, (c) air kolam wadah pem- 
besaran ikan patin dengan perlakuan sistem biopori dan tanpa sisitem biopori di lahan gambut. Pengukuran kualitas air khususnya $\mathrm{pH}$ bertujuan untuk mengetahui kisaran nilai kualitas air pemeliharaan ikan patin di kolam lahan gambut. Ikan patin tersebut dipelihara dengan sistem biopori dan tanpa biopori. Pengukuran $\mathrm{pH}$ air kolam dila-kukan setiap bulan sekali namun jika setelah hujan dapat dilakukan pengu-kuran $\mathrm{pH}$ air kolam untuk mengetahui pengaruh penggunaan biopori pada ko-lam lahan gambut. Kolam lahan gambut ukuran $20 \times 30 \mathrm{~m}^{2}$

Metoda pengukuran $\mathrm{pH}$ yang dilakukan adalah sebagai berikut: (1) pengukuran $\mathrm{pH}$ air menggunakan kertas lakmus. Kertas $\mathrm{pH}$ dicelupkan kedalam air kolam selama beberapa detik dan dibaca hasilnya dengan mencocokkan warna kertas $\mathrm{pH}$ dengan indikator warna; (2) pengukuran $\mathrm{pH}$ dengan menggu-nakan pH-meter. pH-meter dicelupkan kedalam air kolam dan dibaca angka yang muncul secara stabil pada layar pH-meter; (3) pengukuran $\mathrm{pH}$ dilakukan pada pagi hari yaitu pukul 07.00 WIB. Bila pH turun dilakukan perawatan berkala berupa pengapuran kolam de-ngan kapur tohor; dan (4) pengukuran kualitas air selain $\mathrm{pH}$ dilakukan satu bulan sekali bertujuan untuk menge-tahui kisaran nilai kualitas air peme-liharaan ikan patin di kolam lahan gambut. Ikan patin tersebut dipelihara selama 90 hari di kolam lahan gambut.

Metoda pengukuran suhu dan oksigen terlarut yang dilakukan adalah sebagai berikut: (1) pengukuran suhu air menggunakan DO meter yang mempunyai sensor pengukur suhu. DO meter dicelupkan kedalam air kolam selama beberapa lama dan dibaca angka pada layar DO meter; (2) pengukuran oksi-gen terlarut menggunakan DO-meter. DOmeter dicelupkan kedalam air kolam dan dibaca angka yang muncul secara stabil pada layar DO-meter.

\section{Pengukuran pertumbuhan ikan patin}

Peralatan yang digunakan ada-lah: penggaris, timbangan digital, serok, baskom, alat tulis. Parameter yang diamati selama pemeliharaan, adalah: (1) pertumbuhan (panjang dan berat) yang merupakan proses pertambahan ukuran panjang dan berat dalam suatu periode tertentu. Pengambilan data pertum-buhan dilakukan setiap bulan sekali pada masing-masing perlakuan yang meliputi: berat populasi ikan, pertam-bahan berat populasi ikan dan pertum-buhan; (2) pertumbuhan mutlak (GR) yang merupakan proses pertambahan ukuran berat dan panjang dalam suatu periode tertentu. Pertumbuhan mutlak individu terdiri dari pertambahan pan-jang dan berat ikan selama masa pe-meliharaan yang 
dinyatakan dalam per-tambahan berat rata-rata (gram) dan pertambahan panjang baku rata-rata (cm); dan (3) laju pertumbuhan harian (SGR) yang merupakan persentase pertambahan berat ikan setiap harinya selama pemeliharaan, pertumbuhan ha-rian ditunjukkan dalam satuan persen-tase (\%).

\section{HASIL DAN PEMBAHASAN}

\section{Hasil}

Pengukuran kualitas air kolam biopori dan tanpa biopori

Hasil pengukuran kualitas air kolam pembesaran ikan patin di lahan gambut dengan perlakuan kolam bio-pori dan tanpa biopori selama 90 hari pembesaran diperoleh data-data kualitas air kolam seperti terlihat pada Tabel 1., Tabel 2 dan Gambar 1.

Pengukuran pertumbuhan ikan patin di kolam biopori dan tanpa biopori

Pembesaran ikan patin di lahan gambut dilakukan selama 90 hari atau tiga bulan. Setiap bulan dilakukan sampling pertumbuhan berat dan panjang ikan patin untuk mengetahui perbandingan pertumbuhan pada perlakuan yang dilakukan pada tiap kolam. Dari kegiatan kerekayasaan didapatkan pertumbuhan mutlak berat (gram) dan panjang $(\mathrm{cm})$ pada pembesaran ikan patin dengan perlakuan kolam dengan sisitem biopori dan kolam tanpa sistem biopori. Hasil pengukuran pertumbuhan ikan patin pada ke dua kolam dapat dilihat

Tabel 1. Hasil pengukuran kualitas air kolam biopori per bulan

\begin{tabular}{ccccccccccc}
\hline \multirow{2}{*}{$\begin{array}{c}\text { Umur Pemeliharaan } \\
\text { (hari) }\end{array}$} & \multicolumn{9}{c}{ Kolam Biopori } \\
\cline { 2 - 11 } Hari & Bulan & \multicolumn{6}{c}{ Kualitas Air } \\
\hline 0 & 0 & 6,3 & \pm & 0,4 & 27,3 & \pm & 0,4 & 4,3 & \pm & 0,6 \\
30 & 1 & 6,1 & \pm & 0,3 & 27,8 & \pm & 0,4 & 4,1 & \pm & 0,3 \\
60 & 2 & 5,8 & \pm & 0,3 & 27,5 & \pm & 0,0 & 3,9 & \pm & 0,2 \\
90 & 3 & 6,3 & \pm & 0,3 & 28,0 & \pm & 0,0 & 4,3 & \pm & 0,4 \\
\hline
\end{tabular}

Tabel 2. Hasil pengukuran kualitas air kolam tanpa biopori per bulan

\begin{tabular}{|c|c|c|c|c|c|c|c|c|c|}
\hline \multicolumn{2}{|c|}{$\begin{array}{l}\text { Umur Pemeliharaan } \\
\text { (hari) }\end{array}$} & \multicolumn{8}{|c|}{ Kualitas Air Kolam Tanpa Biopori } \\
\hline \multirow{2}{*}{$\begin{array}{c}\text { Hari } \\
0\end{array}$} & \multirow{2}{*}{$\begin{array}{c}\text { Bulan } \\
0\end{array}$} & \multicolumn{3}{|c|}{ pH } & \multicolumn{2}{|c|}{ Suhu $\left({ }^{\circ} \mathrm{C}\right)$} & \multicolumn{3}{|c|}{$\mathrm{DO}(\mathrm{mg} / \mathrm{L})$} \\
\hline & & 6,7 & \pm & 0,3 & 27,6 & $\pm 0,3$ & 5,6 & \pm & 0,6 \\
\hline 30 & 1 & 5,9 & \pm & 0,3 & 28,0 & $\pm 0,0$ & 3,9 & \pm & 0,4 \\
\hline 60 & 2 & 5,1 & \pm & 0,6 & 28,0 & $\pm 0,0$ & 3,2 & \pm & 0,5 \\
\hline 90 & 3 & 5,4 & \pm & 0,5 & 28,0 & $\pm 0,0$ & 3,3 & \pm & 0,4 \\
\hline
\end{tabular}




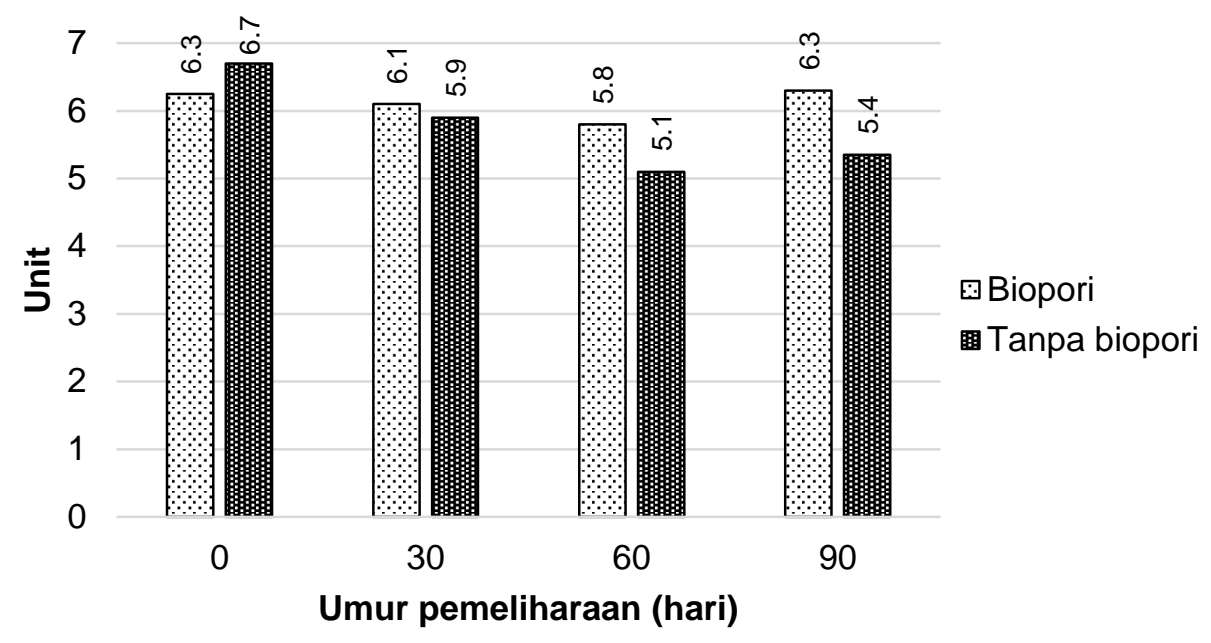

Gambar 1. Grafik pengukuran derajat keasaman $(\mathrm{pH})$ air kolam per bulan

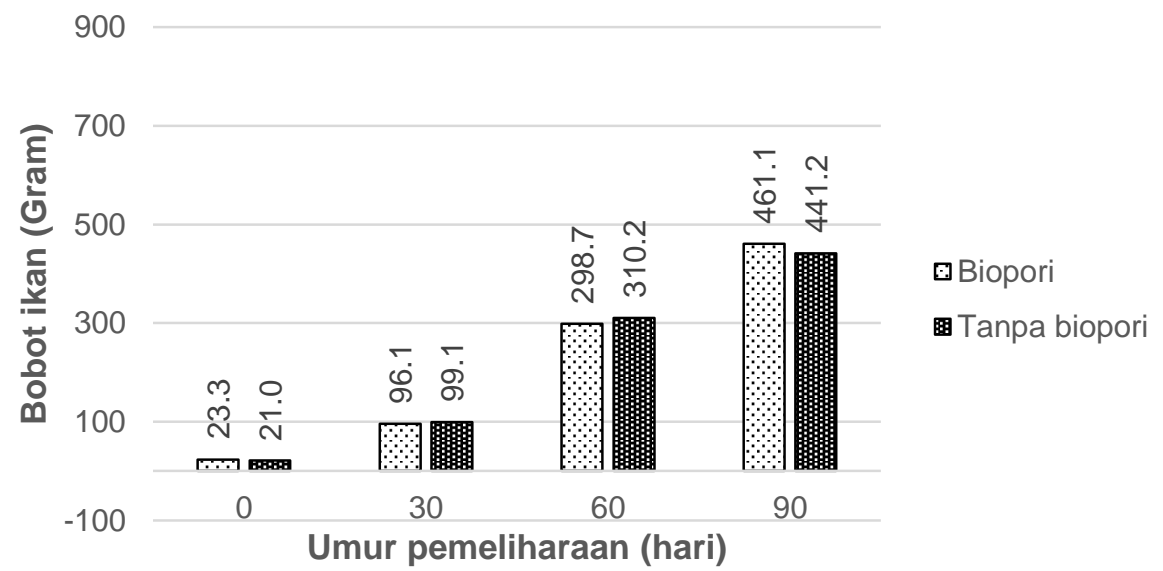

Gambar 2. Bobot ikan patin selama 90 hari kolam biopori dan tanpa biopori

pada Gambar 2. Gambar 3. dan

Gambar 4.

Secara umum, pertumbuhan merupakan fungsi dari pakan, baik kualitas maupun kuantitasnya. Selain itu, faktor yang mempengaruhi pertumbuhan me-liputi faktor internal, seperti faktor genetika; dan faktor eksternal antara lian kualitas air, serangan penyakit. Kedua faktor ini, ada yang dikendalikan dan ada yang tidak dapat dikendalikan.

\section{Pembahasan}

Pengukuran kualitas air kolam biopori dan tanpa biopori

Berdasarkan hasil pengukuran selama 90 hari pembesaran ikan patin di lahan gambut di peroleh data $\mathrm{pH}$ air di kolam dengan sistem biopori berkisar antara 5,8 - 6,3 sedangkan di kolam tanpa biopori $\mathrm{pH}$ air selama pembesaran berkisar antara 5,1-6,7. Tingkat $\mathrm{pH}$ air 


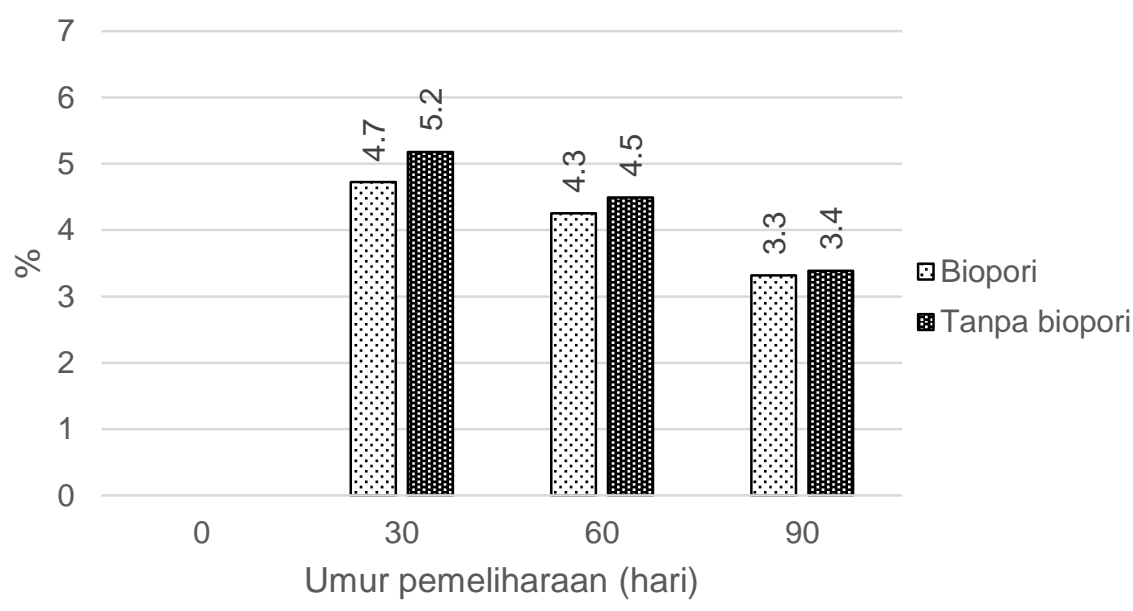

Gambar 3. Laju pertumbuhan bobot harian (LPH)

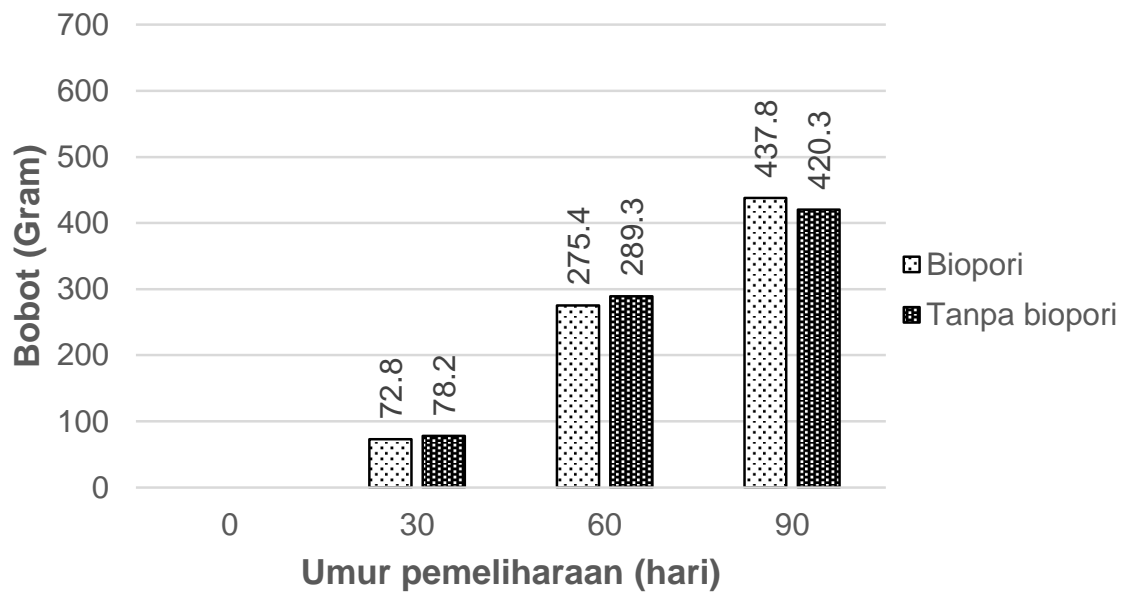

Gambar 4. Pertumbuhan bobot ikan patin

di kolam dengan biopori lebih stabil di bandingkan kolam tanpa biopori walaupun tidak berbeda nyata. Saat awal penebaran $\mathrm{pH}$ air di kolam tanpa bi-opori lebih tinggi dari pada kolam biopori namun menurun saat mulai pemeliharaan ikan. Menurut Syahrizal \& Arifin (2017), menyatakan bahwa ikan kolam air tawar mempunyai titik mati asam pada $\mathrm{pH} 4,0$ dan titik mati basa pada $\mathrm{pH} 11,0$. $\mathrm{pH}$ air kolam di lahan gambut turun karena pengaruh air hujan dan rembesan air dari pinggir kolam yang membawa air asam dan membuat $\mathrm{pH}$ air menjadi turun sehingga perlu pengukuran dan pengontrolan $\mathrm{pH}$ air.

Pada kolam biopori kisaran DO 3,9 - 4,3 sedangkan di kolam tanpa biopori 
berkisar antara 3,2 - 5,6. Nilai oksigen terlarut pada kedua kolam cukup baik untuk menunjang kehidupan ikan patin di lahan gambut karena ma-sih sesuai SNI 01-6483.5-2002. Standar Produksi Ikan Patin Siam (Pangasius hypophthalmus) Kelas Pembesaran di Kolam yaitu nilai DO $\geq 3$. Parameter suhu pada kedua kolam masih sesuai nilai standar pembesaran ikan patin di lahan gambut.

Pengukuran pertumbuhan ikan patin di kolam biopori dan tanpa biopori

Menurut Ariyanto \& Utami (2006) kondisi pertumbuhan partin sangat dipengaruhi oleh sejumlah faktor seperti perbedaan genetik dan keke-rabatan, kemampuan memanfaatkan makanan dan kepadatan populasi. Se-dangkan menurut Amin dkk (2010), makanan yang dimanfaatkan oleh ikan patin, bila terlalu banyak nabati akan berpotensi menimbulkan masalah baru dan mengganggu pertumbuhan. Data pertumbuhan berat/bobot pembesaran ikan patin yang dibesarkan di lahan gambut menunjukkan di kolam biopori pertumbuhannya lebih baik dari pada kolam tanpa biopori walaupun perbedaan pertumbuhannya tidak terlalu jauh. Selama 90 hari pembesaran ikan patin di kolam biopori menghasilkan data pertambahan bobot 437,8 gram sedangkan di kolam tanpa biopori pertambahan bobot 420,3 gram. Laju pertumbuhan harian di kolam biopori ber- kisar antara 3,3 - 4,7\% sedangkan di kolam tanpa biopori berkisar antara 3,4 $5,2 \%$.

\section{SIMPULAN}

Beberapa hal yang dapat disimpulkan dan perlu dilakukan kegiatan kajian aplikasi pembesaran ikan patin dengan sistem biopori di lahan gambut yaitu:

Dari hasil pengujian kualitas air kolam di kolam biopori pH airnya lebih stabil dibandingkan kolam tanpa biopori. Selain kapur yang dimasukkan dalam lubang biopori dapat juga ditambahkan pupuk un-tuk menyuburkan pematang kolam karena tanah gambut miskin akan unsur hara yang membuat tanah tidak subur.

Dari hasil pengukuran pertumbuhan ikan patin di kolam biopori lebih bagus dibandingkan tanpa biopori walaupun tidak berbeda nyata. Se-lain menggunakan teknologi biopri untuk menunjang lingkungan budi-daya juga dapat digunakan tekno-logi penanganan limbah budidaya dengan sistem sedot/siphon limbah.

\section{DAFTAR PUSTAKA}

Amin M, J Dade, DS Ade, N Amrul. 2010. Penggunaan enzim fitase dalam pembuatan pakan ramah lingkungan untuk pakan patin (Pangasius hypopthalmus). Prosi- 
ding Forum Inovasi Teknologi Akuakultur 2010, 781-790.

Ananda T, D Rachmawati, I Samidjan. 2015. Pengaruh papain pada pakan buatan terhadap pertumbuhan ikan patin (Pangasius hypopthalmus). Journal of Aquaculture Management and Technology, 4 (1): 47-53

Andayani S. 2005. Manajemen Kuali-tas Air Untuk Budidaya Perairan. Universitas Brawijaya. Malang

Andiyanto S, E Tahapari, I Insan. 2012. Pendederan ikan patin di kolam outdoor untuk menghasilkan be-nih siap tebar di Waduk Mala-hayu, Brebes, Jawa Tengah. Me-dia Akuakultur, 7 (1): 20-25

Djokosetiyanto D, RK Dongoran, E Supriyono. 2005. Pengaruh alkalinitas terhadap kelangsungan hidup dan pertumbuhan larva ikan patin siam (Pangasius sp.). Jurnal Akuakultur Indonesia, 4 (2): 53-56

Handayani I, E Nofyan. 2015. Optimasi tingkat pemberian pakan bautan terhadap pertumbuhan dan kelangsungan hidup ikan patin jambal (Pangasius djambal). Jurnal Akuakultur Rawa Indonesia, 2(2): 175-187

SNI 01-6483.5-2002. Standar Produksi Ikan Patin Siam (Pangasius hy- pophthalmus) Kelas Pembesaran di Kolam. Jakarta.

Syahrizal S, MY Arifin. 2017. Analisis kandungan merkuri $(\mathrm{Hg})$ pada daging ikan patin siam (Pangasius hypopthalmus) di KJA Danau Sipin Jambi. Jurnal Akuakultur Sungai dan Danau, 2 (1): 9-17 